\title{
Island extinctions: processes, patterns, and potential for ecosystem restoration
}

\author{
JAMIE R. WOOD ${ }^{1}$, JOSEP A. ALCOVER ${ }^{2}$, TIM M. BLACKBURN ${ }^{3,4}$, PERE BOVER $^{2}$, RICHARD \\ P. DUNCAN ${ }^{5}$, JULIAN P. HUME ${ }^{6}$, JULIEN LOUYS ${ }^{7}$, HANNEKE J. M. MEIJER ${ }^{8}$, JUAN C. \\ RANDO $^{9}$, JANET M. WILMSHURST ${ }^{1,10}$ \\ ${ }^{1}$ Landcare Research, Lincoln 7640, New Zealand; ${ }^{2}$ Institut Mediterrani d'Estudis Avançats (CSIC-UIB), Spain; \\ ${ }^{3}$ Department of Genetics, Evolution \& Environment, Centre for Biodiversity \& Environment Research, University \\ College London, Gower Street, London, WC1E 6BT, United Kingdom; ${ }^{4}$ Institute of Zoology, Zoological Society of \\ London, Regent's Park, London, NW1 4RY, United Kingdom; 5 Institute for Applied Ecology, University of Canberra, \\ ACT 2617, Australia; ${ }^{6}$ Department of Life Sciences, Natural History Museum, Akeman St, Tring, Herts HP23 6AP, \\ United Kingdom; ${ }^{7}$ Department of Archaeology and Natural History, School of Culture, History and Languages, The \\ Australian National University, Canberra, ACT, Australia; ${ }^{8}$ University Museum of Bergen, Department of Natural \\ History, University of Bergen, Postboks 78005007 Bergen, Norway; ${ }^{9}$ Departamento de Biología Animal (UDI \\ Zoología), Universidad de La Laguna, La Laguna, Tenerife, Canary Islands, Spain; ${ }^{10}$ School of Environment, The \\ University of Auckland, Private Bag 92019, Auckland 1142, New Zealand.
}

\section{SUMMARY}

Extinction has altered island ecosystems throughout the late Quaternary. Here, we review the main historic drivers of extinctions on islands, the patterns in extinction chronologies between islands, and the potential for restoring ecosystems through reintroducing extirpated species. While some extinctions have been caused by climatic and environmental change most have been caused by anthropogenic impacts. We propose a general model to describe patterns in these anthropogenic island extinctions. A general model describing patterns in anthropogenic island extinctions is proposed. Hunting, habitat loss and the introduction of invasive predators accompanied prehistoric settlement, and caused declines of endemic island species. Later settlement phases by European colonists brought further land development, a different suite of predators, and new drivers leading to more extinctions. Extinctions alter ecological networks, causing ripple effects for islands through the loss of ecosystem processes, functions and interactions between species. Reintroduction of extirpated species and restoration of island ecosystems can help restore ecosystem function and processes, and can be guided by palaeoecology., butHowever, reintroduction projects must also consider the cultural, social and economic needs of humans now inhabiting the islands and ensure resilience against future environmental and climate change. 


\section{INTRODUCTION}

Extinction has played a key role in shaping island biotas and ecosystems. Reduced land area, dispersal barriers and biota with insular adaptations and low population sizes, make island biotas sensitive to environmental, climatic, and anthropogenic pressures and therefore particularly susceptible to extinction (e.g. Manne et al. 1999; Karels et al. 2008). For example, $>90 \%$ of historic bird extinctions were on islands (Johnson and Stattersfield 1990). Whilst the Quaternary fossil record has revealed several 'natural' extinction events on islands (e.g. Louys et al. 2007), these are largely on islands connected to the mainland during glacials. Most island extinctions have arisen via anthropogenic impacts. Extinction and introduction of novel species has transformed island biotic and ecological systems, as the traits of introduced species may not match those of the biota they replace (e.g. Lee et al. 2010). Projects are now underway on islands around the world to restore ecological processes lost through extinction.

Here, we rexplore eview the timing and main historic drivers of extinctions on islands. andTo distill such a complex and detailed topic, we identify common patterns in extinction chronologies between islands. We citinge examples from many archipelagos and wepresent a generalised model for anthropogenic extinctions on islands. We then discuss the model through reviewing in greater depth the rich fossil, archaeological and historical records of New Zealand and the Mascarenes. These two well-documented archipelagos, with contrasting environments, climates and Holocene settlement histories, present ideal case studies for testing the general applicability of the proposed model. I but draw, in particular, we draw, upon the rich well characterisedf ossil, archaeological and historical records from extinction histories of New Zealand (Worthy and Holdaway 2002; Wood 2013; Perry et al. 2014) and the Mascarenes (Cheke and Hume 2008; Cheke 2013) which document species extinctions and introductions to develop a generalised model for anthropogenic extinctions on islands. These two archipelagos, with contrasting environments, climates and Holocene settlement histories, present ideal case studies for testing the general applicability of the proposed model. Finally, we discuss how species introductions have altered the functional composition of island biotas, examine review some recent efforts where palaeoecological records the past haves helped to better inform and guided restoration of island ecosystems, and discuss the continuing threats to, and restoration of, island ecosystems.

\section{PLEISTOCENE ENVIRONMENTAL AND CLIMATIC DRIVERS OF EXTINCTION ON ISLANDS}

Changing sea levels during the Pleistocene created land bridges to islands or reduced island areas, facilitating migrations and extinction. For example, during the late Middle Pleistocene, the formation of a land-bridge between the continental island of Sicily and the European mainland led to the replacement of the highly-endemic Sicilian fauna by a mainland fauna (Bonfiglio et al. 2002). Details of such events are difficult to resolve because the fossil record becomes more incomplete and dating less precise with age. Moreover, the Pleistocene arrival of hominins on islands is poorly constrained (small populations may be difficult to detect in archaeological records) and likely coincided with significant environmental and climatic change. In such instances disentangling the 
contributions of environmental and anthropogenic drivers to island extinctions can prove as complex as it has been for continents (e.g. Barnosky et al. 2004).

The Malay ArchipelagoIsland South East Asia provides examples of prehistoric extinctions caused by environmental change. During glacials, most current Sundanese islands were connected by savannah corridors that facilitated dispersal of terrestrial biota (Heaney 1991; Bird et al. 2005; Louys and Meijaard 2010). While several faunal turnover events were associated with glacial connections, the interglacial loss of savannahs is thought responsible for most Pleistocene large mammal extinctions in this region (Louys et al. 2007; Louys 2008; 2014). The earliest Homo on Java, Indonesia, date to the Early Pleistocene (Swisher et al. 1994) but there is no evidence suggesting they contributed to local extinctions (Louys et al. 2007). Moreover, the appearance of hominins on islands in the region at ca.>200 ka (van den Bergh et al. 2016) does not coincide with extinctions, even though they hunted local faunas (Morwood et al. 2008; Piper et al. 2008; van den Bergh et al. 2016). On some islands of Nusa Tenggara, Indonesia, extinctions either pre-dated or significantly post-dated the arrival of humans, implicating environmental or natural demographic processes for the former, and technological innovations for the latter (e.g. Glover 1986; Louys et al. 2016).

On Bermuda, rising sea levels at ca.400 ka reduced land area and caused the extinction of four endemic bird species (Olson and Wingate 2000; Hearty et al. 2004). However, on most remote oceanic archipelagos, biotic communities were resilient to major climatic and environmental change throughout the Pleistocene, and background rates of extinction were exceedingly low. For example, on the Galápagos Islands just 0-3 vertebrate populations were lost in the $4-8$ ka period preceding human arrival (Steadman 2006). In New Zealand, there are were no known extinctions during the 50 ka preceding human settlement, and evidence suggests that many species tracked changes in habitat as the climate warmed after the last glacial maximum (Rawlence et al. 2012).

\section{HOLOCENE ANTHROPOGENIC DRIVERS OF EXTINCTION ON ISLANDS}

Extinction rates on islands increased dramatically during the Holocene. Even on islands settled during the Pleistocene, extinction rates increased during the Holocene after human populations became more technologically advanced and less nomadic. For example, in the Malay archipelagoIsland South East Asia the development of complex hunting tools and the beginning development of swidden agriculture and large-scale deforestation at the beginning of the Holocene (e.g. Maloney 1980; 1985; Rabett and Piper 2012; Hunt and Rabett 2014) contributed more to extinctions and extirpations than initial Pleistocene colonisation (Sodhi et al. 2004; Morwood et al. 2008; Corlett 2007; Louys 2008). TApart from some inter-island variability, there is overall a remarkablye consistentcy three-phase pattern to the progression of anthropogenic extinctions on islands first visited or settled during the Holocene., and wWe presentsummarise this through a generalised model for theis process here (Fig. 1).

Here, we propose a general model for the remarkably consistent nature of anthropogenic extinction chronologies for islands first visited or settled during the Holocene (Fig 1).

\section{Holocene extinction phase 1: Pre-settlement visitation}


Many islands were visited by people prior to settlement, and others were visited but never settled. Visitors often introduced alien predators which caused extinctions. For example, the house mouse (Mus musculus) was introduced to Madeira no later than ca.903-1036 AD, some 400 years prior to settlement. Its impact may have been severe, especially on seabirds and small flightless birds (Rando et al. 2014). The pre-settlement introduction of mammals in the Mascarenes also caused several bird extinctions (Cheke 2013). The introduction of black rat (Rattus rattus) by Arab traders during the 14th Century to the Mascarenes (Cheke 2013, Hume 2013) caused the extinction of a large skink (Leiolopisma mauritiana), an endemic starling (Cryptopsar ischyrhynchus) (Hume 2014a), and at least three undescribed passerine species (Hume 2013). On the subantarctic Macquarie Island, which has never been permanently settled, an endemic parakeet became extinct following the introduction of rabbits, which increased local predator populations causing increased predation (Taylor 1979).

\section{Holocene extinction phase 2: Initial Prehistoric or prehistoric or initial settlement events}

During the Holocene many islands were first settled by a founding group, and then much later, by Europeans. Others had multiple prehistoric settlement events. Almost always initial settlementthese coincided with an increase in extinctions, though the severity and rate of extinctions varied between islands (e.g. Turvey et al. 2007; Perry et al. 2014) due to factors such as composition of the native fauna and which commensal species were introduced. The three major drivers of extinction associated with initial or prehistoric human settlement of islands were the introduction of predators (and any associated pathogens or diseases), hunting, and firing of vegetation burning.

\section{Alien species}

While commensal introduced plants cultigens appear to have had relatively little impact on native plant speciescommunities (other than indirectly through forest clearance), introduced fauna drove extinctions in biota susceptible to the specific traits of the introduced species. For example, the introduction of the Pacific rat (Rattus exulans) caused extinctions among small flightless and groundnesting birds, terrestrial beetles and numerous other invertebrates on east Polynesian islands (Worthy \& Holdaway 2002; Roff \& Roff 2003; Steadman 2006; Hunt 2007; Liebherr and Porch 2015).

Other taxa intentionally introduced included crop and fibre species, fauna for protein resources (e.g. goats [Capra hircus] and pigs [Sus scrofa]) and hunting aids such as dogs (Canis familiaris) (Schüle 1993; Prebble 2008; Anderson 2009). On some remote oceanic islands (for example New Zealand) following the initial establishment phase there is usually little or no evidence for any subsequent introductions during the prehistoric settlement period, suggesting that travel back to homelands was ould have been limited after a few centuries (Fig. 1). On this archipelago and many others (for example...__ fFurther introductions of alien taxa only occurred later in the before resuming again during the secondary subsequent settlement phases.

\section{Hunting}

Insular megafauna (the largest animals within an island ecosystem irrespective of actual body mass, sensu Hansen and Galetti 2009) typically disappeared rapidly after human arrival during the 
Holocene (e.g. Perry et al. 2014). Factors implicated in their loss include predation by commensal species (Fleming 1969), environmental change (Clarke et al. 2006), loss of prey and habitat (Worthy and Holdaway 2002: 335), and introduced pathogens (Bover and Alcover 2003). However, hunting was the key driver. Extensive archaeological bone middens and historic records show this was the case with birds ca.>4 kg in New Zealand (Duncan et al. 2002; Roff and Roff 2003; Worthy and Holdaway 2002; Perry et al. 2014), and similarly with large birds and reptiles of islands in the Indian (Cheke and Bour 2014) and Pacific Oceans islands (e.g. Steadman et al. 2002). A possible exception is the extinction of many Mediterranean island megafauna species, asbecause, although their extinction closely coincides with human arrival, there is no definitive evidence for human involvement (Bover and Alcover 2003; Vigne et al. 2009; Zazzo et al. 2015; Bover et al. 2016). The case for hunting driving Holocene extinction of megafauna is nevertheless well established on islands compared to continents, where the roles of humans and climate change remain contested.

\section{Fire}

Prehistoric settlement of islands during the Holocene was often accompanied by rapid loss of natural vegetation (particularly forest) through fire, the rate of which declined as dry, easily burnt areas were lost (Fig. 1). In dry, fire-prone regions with low rates of natural ignition, modelling shows prehistoric deforestation required intentional burning rather than random ignitions (Perry et al. 2012). This may have been to clear forest for swidden agriculture (e.g. Weisler 1995; Bowman et al. 2011; Wilmshurst et al. 2014), for travelimproving access to resources (McGlone et al. 2005) or even for hunting. Initial rates of vegetation loss were may have been accelerated by positive feedbacks that promoted early successional flammable plant species (Perry et al. 2012). On larger, climatically diverse islands, such as New Zealand, forest was cleared from dry lowland regions within decades (McWethy et al. 2014) but remained atin higher elevations and in wetter areas. Conversely, many smaller islands suffered near total loss of forests ( $<2 \%$ remaining in Mauritius; Page and D'Argent 1997; Cheke and Hume 2008) or complete clearance (e.g. Rapa Nui; Flenley et al. 1991). Deforestation not only destroyed faunal habitat but also drove plant extinctions (e.g. Hunt 2007; Athens 20082009; Prebble and Dowe 2008; Connor et al. 2012).

\section{Holocene extinction phase 3: Historic or secondary European settlement}

Many islands initially settled during prehistory were subsequently colonised by Europeans (Grove 1996). Others were first settled during historic recent times. The same drivers of extinction associated with prehistoric or initial settlement are often replicated in historicrecent, or secondaryEuropean, settlement phases, but with slight variations (Fig. 1).

New suites of alien species, introduced accidentally or deliberately by for acclimatisation societies (sensu Dunlap 1997), biological control or economic reasons, increased the functional diversity of predator communities, thereby putting a wider range of native species at risk and resulting in further extinctions (Fig. 1). For example, the introduction of the weasel (Mustela nivalis) to Mallorca and Menorca ca. $2 \mathrm{ka}$ after initial settlement extirpated the endemic lizard Podarcis lilfordi from both islands (Valensuela and Alcover 2013). The lizard is now restricted to weasel-free islets. Another clear demonstration of this pattern is the positive relationship between the number of bird extinctions 
and introduced predator species following European arrival on oceanic islands (Blackburn et al. 2004). Herbivore introductions have led to declines and extinctions of plant species (de Lange et al. 2004) and increased soil erosion, degrading habitat quality and leading to extinctions. For example, erosion and a decline in palm forest following rabbit and goat introduction to Mauritius in 1840 may have contributed to the extinction of the burrowing boa (Bolyeria multicarinata) (Bullock and North 1984). Invasive plants have also contributed to the displacement and decline of native island plant species (e.g. Meyer and Florence 1996; Loope et al. 2013). Although there are far fewer examples of island plant extinctions than animal extinctions, the rate of plant species naturalizations continues steadily and there may be due to an extinction debt yet to be realised (Sax and Gaines 2008).

Hunting or harvesting of island fauna continued during the historic settlement phase, but, as many of the large, slow-reproducing species most susceptible to hunting had already gone extinct following initial settlement, resulted in fewer extinctions. However, over-harvesting during the third phase has been responsible for continuing loss of a wide range of island species, both terrestrial and marine (Thaman 2002).

Increased forest clearance (Fig. 1) for timber and agriculture accompanied historical settlement, causing significant reductions of some landsnail and beetle faunas (e.g. Goodfriend et al. 1994; Griffiths and Florens 2006; Terzopoulou et al. 2015). In Mauritius, most plant extinctions (70 species, or $10.4 \%$ of the Mauritian flora [Atkinson and Sevathian 2007]) resulted from forest clearance and over-grazing (Page and D'Argent 1997; Atkinson and Sevathian 2007; Cheke and Hume 2008). Over-grazing has also been implicated in plant losses on the Galápagos (Bush et al. 2014) and in New Zealand (deLange et al. 2004). On some islands rates of forest loss have declined (e.g. Ewers et al. 2006) but on others continue to rise (e.g. Margono et al. 2014).

In addition to these three pervasive factors, several new drivers are associated with more recent extinctions. Draining of wetlands for agriculture and disease prevention (affecting up to 87\% of global wetlands since 1700 AD [Davidson 2014]) has contributed to island extinctions (Steadman 1996). Novel pathogens and diseases have caused the decline of many island species (Wikelski et al. 2004), a recent example being Hawaiian bird species and mosquito-borne avian malaria (Warner 1968). The potential role of pathogens and diseases in older island extinctions has been suggested (e.g. Bover and Alcover 2003) and may have been more significant than appreciated. A convincing demonstration is the Christmas Island rat (Rattus macleari), for which DNA of a novel pathogenic trypanosome has been detected in museum specimens collected after the introduction of Black rats (Wyatt et al. 2008). Specimen collection for scientific purposes is also a relatively recent pressure, but its role in causing extinctions has been debated (Minteer et al. 2014; Rocha et al. 2014) and is perhaps overstated. Collection may not independently drive extinction, but collecting may have at least hastened extinction of some island species already in decline (e.g. huia, Heteralocha acutirostris).

\section{General model of Holocene anthropogenic extinctions on islands: case studies}

Resolving the sequence and timing of anthropogenic impacts and associated extinctions depends on robust fossil, archaeological and historical records, and large numbers of accurately dated specimens. Very few islands meet all these criteria. However, the Mascarenes and New Zealand offer rich, long- 
term records of species extinctions and introductions (Fig. 2). These two archipelagos, with contrasting environments, climates and Holocene settlement histories, present ideal case studies for testing the general applicability of the proposed model.

The Mascarenes were visited prior to settlement (Phase 1) and the black rat, crab-eating macaque (Macaca fascicularis) and pig introduced (Fig. 2) causing faunal extinctions (Cheke 2013). The Rodrigues blue pigeon (Alectroeanas payandeei) and a Mauritius population of Réunion harrier (Circus maillardi) disappeared, while much of the native fauna declined (Hume 2013). However, most endemic species survived until historic settlement (Phase 3). Most predatory mammal introductions occurred before 1900 (Fig. 2), reflecting a declining rate of introductions (as in Fig. 1). Increased bird extinction rates on all three mains islands (Mauritius, Rodrigues and Réunion) coincided with the local timing of predatory mammal introductions (Fig. 2). On Mauritius and Réunion this occurred between 1638-1695, causing the loss of all flightless birds, and increased hunting pressure and habitat destruction resulted in a second wave of extinctions between 1710 1840. Rodrigues, the most isolated of the islands, remained unsettled until the late 18th century, but lost almost all its native fauna between 1726-1761 (Hume 2013). The extinction of large tortoises on Mauritius (ca.1715), Rodrigues (ca.1795) and Réunion (ca.1850) appears to have been related to harvesting rather than introduced predators or habitat loss (Cheke 2013).

There is no evidence for pre-settlement visitation (Phase 1) to New Zealand, which was first settled by Polynesians during the early $13^{\text {th }}$ Century AD (Wilmshurst et al. 2008) (Phase 2), when two predatory mammal species were introduced (Pacific rat and dog) (Fig. 2). After this there were is no evidence for furthermore species introductions until the second European settlement phase, beginning in the late $18^{\text {th }}$ Century (as in Fig. 1). A period of rapid deforestation (McWethy et al. 2014) and extinction followed initial settlement. The New Zealand moa (Aves: Dinornithiformes) are constitute perhaps the best resolved prehistoric island extinction, with hundreds of radiocarbon dates revealing extinction within 200 years (Perry et al. 2014). Many other large bird species disappeared at the same time (e.g. geese [Cnemiornis spp.] and adzebills [Aptornis spp.]) suggesting these first two centuries were a time of rapid exploitation and extermination (as in Fig. 1). There is also evidence for rapid Phase 2 extinctions on larger islands in Near Oceania (Steadman et al. 2002; Steadman 2006) and high prehistoric extinction rates of birds on other Pacific iIslands (Duncan et al. 2013). While it has been suggested that humans co-existed with extinct species on some Pacific iIslands for much longer periods (Steadman 2006), uncertainty in the exact timing of human settlement on some island groups makes this dubiousmay account partly for this (Steadman 2006; Prebble and Wilmshurst 2009). Recent work has shown settlement occurred more recently than previously thought on many of these islands (Wilmshurst et al. 2014), supporting the idea of rapid extinctions following human arrival. With few or no subsequent species introductions, and a reduction in vegetation clearance, the rate of extinction likely declined with time in phase 2 (as in Fig. 1).

After the arrival of James Cook's expedition in 1769 and the likely contemporaneous introduction of cats (Felis domesticus) and Norway rats (Rattus norvegicus), the second period of New Zealand settlement began (in the early $19^{\text {th }}$ Century, (i.e. Phase 3). The rate of predatory mammal introductions has declined (as in Fig. 1): seven species became established during the $19^{\text {th }}$ Century but none have done so since (Fig. 2). The combined impacts of these mammals resulted in an 
increased rate of faunal extinctions in the latter part of the $19^{\text {th }}$ Century (Fig. 2). With no more predatory mammal introductions, the extinction rate declined by the early $20^{\text {th }}$ Century, with the exception of three extinctions on Big South Cape Island following the arrival of rats there in the 1960s (Bell et al. 2016) (Fig. 2).

\section{ECOLOGICAL CONSEQUENCES OF ISLAND EXTINCTIONS}

There is a wide range of literature exploring how Eextinctions can sever ecological interactions, affecting ecosystem processes and functions on islands. (e.g. Meehan et al. 2002; Johnson 2009; Hansen 2010; Lee et al. 2010). The effects can cascade across ecological networks and take centuries to be fully realised (Brodie et al. 2014). For species with specialised interactions, the extinction of one species may cause the loss of others (i.e. co-extinction). On islands, co-extinction is a risk for specialised insect pollinated plants (Dunn et al. 2009) or faunal-dispersed plants (e.g. Meehan et al. 2002) and has caused the loss of many host-specific parasites (e.g. Mey 1990; Wood et al. 2013).

Extinctions are biased towards taxa with susceptible traits (Roff and Roff 2003; Duncan and Blackburn 2004), causing heavy losses in certain trophic groups (Johnson 2009; Hansen and Galetti 2009). For example, large vertebrate herbivores are prone to extinction, causing 'trophic skew' (Duffy 2003), altering plant communities and ecosystem function. In New Zealand, the loss of all $>$ ca. $4 \mathrm{~kg}$ avian herbivores species may have altered dynamics in avian-induced vegetation communities (Lee et al. 2010) and had minor effects on abundances of some forest plants (Wood and Wilmshurst 2017). Loss of ecosystem engineer species can also have profound effects. Seabirds, for example, transport large amounts of nutrients into terrestrial ecosystems and burrow into soils, influencing vegetation (Smith et al. 2011) but, since human settlement, seabird communities have been been severely impacted on islands around the world (e.g. Steadman 1995; Worthy and Holdaway 2002; Rando and Alcover 2007).

While some exotic species may perform ecological roles approximating those of extinct species (Hansen 2010), there are many specialised ecological roles performed by extinct island species that no exotic species could entirely replace. Moreover, exotic species seldom offer complete replacement for extinct biota at the community-level. Exotic species are largely ineffective in performing the ecological role of extinct species on islands. In birds, for example, even if the number of species introduced to an island approximates the number of those extinct ones, the ecological traits and phylogenetic diversity are rarely comparable leading to significantly different functional assemblages (Sobral et al. 2016). This may partly be because exotic species favour non-native habitats (Lee et al. 2010). A comparison of broad trophic groups of extinct and extant bird species from New Zealand and the Mascarenes (Fig. 3) shows that invertebrate and seed consumers are better represented currently due to the post-settlement expansion of grasslands (Lee et al. 2010). However, patterns for other groups are inconsistent; New Zealand is now depauperate in terrestrial foliovores, whereas this guild is enriched in the Mascarenes, and the opposite is true for aquatic plant feeders, frugivores and vertebrate predators (Fig. 3).

Removal of exotic species is a key aspect of island conservation (Keitt et al. 2011) but restoring lost ecosystem processes and functions is a further step requiring knowledge about pre-human states. 
Fossil records are the key to such information, which can help guide restoration efforts (Barnosky et al. 2017).

\section{USING THE PAST AS A GUIDE FOR RESTORATION}

Fossil deposits record the composition of, and interactions between, species in pre-disturbance ecosystems and can form baselines to guide 're-wilding' (e.g., Van Leeuwen 2008; Wilmshurst et al. 2014; Barnosky et al. 2017). While 're-wilding' has been widely discussed for continents, the relatively recent extinctions and smaller scale of islands (Hansen \& Galetti 2009) make them better candidates (Hansen 2010). Yet, while many islands have had past biotic communities reconstructed from fossil deposits, this understanding has had little influence on management and restoration. The potential for palaeoecology to help us better understand past island ecosystems, and some examples of practical uses, are presented below.

\section{Restoration of island vegetation communities}

Palaeoecology shows how island habitats have changed following settlement, identifies plant extinctions, and sheds light on the implications. Moreover, palaeoecological records can reveal the suitability of a site for different plant species, thereby increasing the range considered for replanting (Burney and Burney 2015). Limited taxonomic resolution of some palaeoecological proxies means that determining exact species may be problematic (e.g. Chapin et al. 2004), but prehistoric baselines are useful at a broad scale. For example, the natural vegetation of Tawhiti Rahi, (off northern New Zealand), was thought to be low-statured pohutakawa (Metrosideros excelsa) forest. However, pollen and DNA from a soil core showed that before settlement the island was in tall podocarp forest with a palm-rich understorey (Wilmshurst et al. 2014). On San Cristobal Island, (Galápagos), pollen records showed that replanting strategies were based on a heavily modified system rather than the natural 'pre-grazing' shrubland (Bush et al. 2014). On the Galápagos, pollen and macrofossils have shown that plants considered 'doubtful natives' were present before settlement, and their management has been adjusted (Coffey et al. 2011).

An exceptional example is at the Makauwhai Makauwahi Cave Reserve, (Kauai), w. Hhere, replanting of 81 plant species (22 absent from the area) has been guided by their presence in late Holocene deposits, using a reference point in the early post-settlement period (Burney and Burney 2015).

\section{Reintroduction of extirpated animal species to islands}

A wide range of taxa including birds, mammals, invertebrates (e.g. Watts et al. 2008), amphibians and reptiles (Dodd and Seigel 1991) have been translocated back to islands from where they had been extirpated. For example, since 1863 in New Zealand there have been >1100 attempts to translocate 55 bird species (41 successfully) (Miskelly and Powlesland 2013). While six taxa have been translocated beyond their 'natural' ranges, the remainder represent reintroductions (Miskelly and Powlesland 2013). Although these translocations were primarily for conservation of the birds (i.e. moving to predator-free sanctuaries), they also restore ecological processes. 
There may be a specific case for translocating certain species to restore ecosystem processes (e.g. seabirds; Miskelly et al. 2009) or interactions (Seddon et al. 2014). For example, analysis of a Holocene coprolite of the New Zealand kakapo (Strigops habroptilus) revealed abundant pollen of the threatened plant Dactylanthus taylorii, suggesting a pollination relationship (Wood et al. 2012). This could only have been detected using palaeoecology, as kakapo and Dactylanthus populations no longer overlap. Dactylanthus was assumed to have only been pollinated by a bat, and rarity of the bat regarded as a limitation to translocation of the plant (Ecroyd 1995).

\section{Restoring ecological function to islands using analogues for extinct species}

Translocation of faunal species has been used to 'rewild' islands. In the most simplest scenario, extant close phylogenetic-relatives of the extinct species are used as surrogates. Giant tortoises on Indian Ocean islands performed many important functions and experiments on Mauritius and Rodrigues using Aldabra giant and radiated tortoises as surrogates for the extinct endemic species have shown that native seeds passing through tortoises have extremely high germination rates (Griffiths 2014). Tortoises are also 'de-weeders', and their faeces and urine provide vital soil nutrients, making tortoises ideal candidates for rewilding projects on Mauritius and Rodrigues (Griffiths et al. 2011; Griffiths 2014; Hume 2014b), Madagascar (Pedrono et al. 2013), Galápagos (Gibbs et al. 2008) and in the Caribbean (Hansen et al. 2010). In New Zealand the extant North Island kokako (Callaeas wilsoni) has been released on Secretary Island to restore the ecological functions of the extinct South Island kokako (C. cinerea) (Seddon et al. 2012). Use of phylogenetic relatives to restore extinct plants and birds has also been advocated for Lord Howe Island (Hutton et al. 2007).

In more radical scenarios, extant species more distantly related to the extinct species might be considered as surrogates. On Kauai, African spurred tortoises (Centrochelys sulcata) benefit native vegetation communities by suppressing undergrowth (presently dominated by invasive species), increasing soil nutrients and aiding seed germination (Burney and Burney 2016); these are functions once provided by a now-extinct community of large grazing waterfowls (Burney and Burney 2016).

Rewilding may provide improvement to island ecosystems, but has inherent difficulties and potentially unforeseen consequences (Nogués-Bravo et al. 2016). Given the risks of introducing species to islands, island rewilding projects should to be underpinned by consideration of issues such as the similarity of ecological roles with extinct taxa, potential threats to survival, available stock, and rigorous risk/benefit analysis (Seddon et al. 2014; Louys et al. 2014).

\section{CONCLUSIONS}

Islands have a long history of natural extinction from climatic and environmental changes, but extinction rates have increased dramatically through anthropogenic impacts during the Holocene. General We have identified some general patterns exist in terms of the interactions between human settlement phases, exotic species introductions, vegetation clearance and extinction rates (Fig. 1), yet 
further research (particularly on islands with multiple phases of prehistoric settlement) may help refine the model.

Island extinctions are have not yet ceasdedfinished. The extinction debt (e.g. Triantis et al. 2010), and threats to island species (e.g. via continued loss of native vegetation and new invasive species) are ongoing (Manne et al. 1999; Sax and Gaines 2008). Moreover, anthropogenic climate change may also represent a new driver of island extinctions (Benning et al. 2002).

Palaeoecological records provide insights into intact pre-human island ecosystems crucial to restoration goals. However, returning island ecosystems to prehistoric states may not always be possible, or desirable. Humans are now integral parts of island ecosystems, and restoration projects now often combine traditional knowledge and human desires with palaeoecological evidence, to accommodate cultural, social and economic outcomes in addition to ecological ones (Lyver et al. 2015; Russell et al. 2017). The challenge for the numerous restoration projects underway will be to offset biodiversity loss through continued spread of invasive species and climate change (with associated sea-level rise, reduced land area and habitat loss). Developments such as novel pest control systems and de-extinction (Shapiro 2015), and visionary targets such as removing exotic predators from entire archipelagos (Russell et al. 2015), may offer new avenues for slowing extinction and restoring island ecosystems.

\section{Acknowledgments}

We thank M. McGlone and two anonymous referees for comments that greatly improved this manuscript.

\section{References}

Anderson, A. (2009) The rat and the octopus: initial human colonization and the prehistoric introduction of domestic animals to remote Oceania. Biological Invasions 11: 1503-1519.

Athens, J.S. (20082009) Rattus exulans and the catastrophic disappearance of Hawai'i's native lowland forest. Biological Invasions 11: 1489-1501.

Atkinson, R. \& Sevathian, J.C. (2007) A guide to the plants of Mauritius. Mauritius: Mauritius Stationary Manufacturers Ltd.

Barnosky, A.D., Koch, P.L., Feranec, R.S., Wing, S.L., Shabel, A.B. (2004) Assessing the causes of Late Pleistocene extinctions on the continents. Science 306: 70-75.

Barnosky, A.D., Hadly, E.A., Gonzalez, P., Head, J., Polly, P.D., Lawing, A.M., et al. (2017) Merging paleobiology with conservation biology to guide the future of terrestrial ecosystems. Science 355: eaah4787.

Bell, E.A., Bell, B.D. \& Merton, D.V. (2016) The legacy of Big South Cape: rat irruption to rat eradication. New Zealand Journal of Ecology 40: 212-218. 
Benning, T.L., LaPointe, D., Atkinson, C.T. \& Vitousek, P.M. (2002) Interactions of climate change with biological invasions and land use in the Hawaiian Islands: Modeling the fate of endemic birds using a geographic information systems. Proceedings of the National Academy of Sciences USA 99: $14246-14249$.

Bird, M. I., Taylor, D. \& Hunt, C. (2005) Palaeoenvironments of insular Southeast Asia during the Last Glacial Period: a savanna corridor in Sundaland? Quaternary Science Reviews 24: 2228-2242.

Blackburn, T.M., Cassey, P., Duncan, R.P., Evans, K.L. \& Gaston, K.J. (2004) Avian extinction and mammalian introductions on oceanic islands. Science 305: 1955-1958.

Bonfiglio, L., Mangano, G., Marra, A.C., Masini, F., Pavia, M. \& Petruso, D. (2002) Pleistocene Calabrian and Sicilian paleobioprovinces. Geobios, Mémoire spécial 24: 29-39.

Bover, P. \& Alcover, J.A. (2003) Understanding Late Quaternary extinctions: the case of Myotragus balearicus (Bate, 1909). Journal of Biogeography 30: 771-781.

Bover, P., Valenzuela, A., Torres, E., Cooper, A., Pons, J. \& Alcover, J.A. (2016) Closing the gap: New data on the last documented Myotragus and the first human evidence on Mallorca (Balearic Islands, Western Mediterranean Sea). The Holocene 26: 1887-1891.

Bowman, D.M.J.S., Balch, J., Artaxo, P., Bond, W.J., Cochrane, M.A., D’Antonia, C.M., et al. (2011) The human dimension of fire regimes on Earth. Journal of Biogeography 38: 2223-2236.

Brodie, J.F., Aslan, C.E., Rogers, H.S., Redford, K.H. \& Maron, J.L. (2014) Secondary extinctions of biodiversity. Trends in Ecology \& Evolution 29: 664-672.

Bullock, D. \& North, S. (1984) Round Island in 1982. Oryx 18: 36-41.

Burney, D.A. \& Burney, L.P. (2016) Monitoring results from a decade of native plant translocations at Makauwahi Cave Reserve, Kaua`i. Plant Ecology 217: 139-153.

Bush, M.B., Restrepo, A. \& Collins, A.F. (2014) Galápagos history, restoration, and a shifted baseline. Restoration Ecology 22: 296-298.

Chapin, M.H., Wood, K.R., Perlman, S.P. \& Maunder, M. (2004) A review of the conservation status of the endemic Pritchardia palms of Hawaii. Oryx 38: 273-281.

Cheke, A.S. (2013) Extinct birds of the Mascarenes and Seychelles - a review of the causes of extinction in the light of an important new publication on extinct birds. Phelsuma 21: 4-19.

Cheke, A.S. \& Bour, R. (2014) Unequal struggle - how humans displaced the dominance of tortoises in island ecosystems. Pp. 31-120 in Gerlach, J. (ed.). Western Indian Ocean Tortoises. Manchester: Siri Scientific Press.

Cheke, A.S. \& Hume, J.P. (2008) Lost land of the Dodo: the ecological history of the Mascarene Islands. London: A. \& C. Black Publishers. 
Clarke, S.J., Miller, G.H., Fogel, M.L., Chivas, A.R., Murray-Wallace, C.V. (2006) The amino acid and stable isotope biogeochemistry of elephant bird (Aepyornis) eggshells from southern Madagascar. Quaternary Science Reviews 25: 2343-2356.

Coffey, E.E.D., Froyd, C.A. \& Willis, K.J. (2011) When is an invasive not an invasive? Macrofossil evidence of doubtful plant species in the Galápagos Islands. Ecology 92: 805-812.

Connor, S.E., van Leeuwen, J.F.N., Rittenour, T.M., van der Knaap, W.O., Ammann, B. \& Björck, S.B. (2012) The ecological impact of oceanic island colonization - a palaeoecological perspective from the Azores. Journal of Biogeography 39: 1007-1023.

Corlett, R.T. (2007) The impact of hunting on the mammalian fauna of tropical Asian forests. Biotropica 39: 292-303.

Davidson, N.C. (2014) How much wetland has the world lost? Long-term and recent trends in global wetland area. Marine and Freshwater Research 65: 934-941.

deLange, P.J., Norton, D.A., Heenan, P.B., Courtney, S.P., Molloy, B.P.J., Ogle, C.C., et al. (2004) Threatened and uncommon plants of New Zealand. New Zealand Journal of Botany 42: 45-76.

Dodd, C.K. \& Seigel, R.A. (1991) Relocation, repatriation, and translocation of amphibians and reptiles: are they conservation strategies that work? Herpetologica 47: 336-350.

Duffy, J.E. (2003) Biodiversity loss, trophic skew and ecosystem functioning. Ecology Letters 6: $680-687$.

Duncan, R.P. \& Blackburn, T.M. (2004) Extinction and endemism in the New Zealand avifauna. Global Ecology and Biogeography 13: 509-517.

Duncan, R.P., Blackburn, T.M. \& Worthy, T.H. (2002). Prehistoric bird extinctions and human hunting. Proceedings of the Royal Society B 269: 517-521.

Duncan, R.P., Boyer, A.G. \& Blackburn, T.M. (2013) Magnitude and variation of prehistoric bird extinctions in the Pacific. Proceedings of the National Academy of Sciences USA 110: 6436-6441.

Dunlap, T.R. (1997) Remaking the land: the acclimatization movement and Anglo ideas of nature. Journal of World History 8: 309-319.

Dunn, R.R., Harris, N.C., Colwell, R.K., Koh, L.P. \& Sodhi, N.S. (2009) The sixth mass coextinction: are most endangered species parasites and mutualists? Proceedings of the Royal Society B 276: 3037-3045.

Ecroyd, C.E. (1995) Dactylanthus taylorii recovery plan. Department of Conservation, Wellington, New Zealand.

Ewers, R.M., Kliskey, A.D., Walker, S., Rutledge, D., Harding, J.S. \& Didham, R.K. (2006) Past and future trajectories of forest loss in New Zealand. Biological Conservation 133: 312-325.

Fleming, C.A. (1969) Rats and moa extinction. Notornis 16: 210-211. 
Flenley, J.R., King, A.S.M., Jackson, J., Chew, C., Teller, J.T., Prentice, M.E. (1991) The Late Quaternary vegetational and climatic history of Easter Island. Journal of Quaternary Science 6: 85115.

Gibbs, J.P., Marquez, C. \& Sterling, E.J. (2008) The role of endangered species reintroduction in ecosystem restoration: tortoise-cactus interactions on Española Island, Galapagos. Restoration Ecology 16: 88-93.

Glover, I. (1986) Archaeology in Eastern Timor, 1966-67. Terra Australis 11: 1-241.

Goodfriend, G.A., Cameron, R.A.D. \& Cook L.M. (1994) Fossil evidence of recent human impact on the land snail fauna of Madeira. Journal of Biogeography 21: 309-320.

Griffiths, C.J., Hansen, D.M., Jones, C.G., Zuēl, N. \& Harris, S. (2011) Resurrecting extinct interactions with extant substitutes. Current Biology 21: 1-4

Griffiths, C.J. (2014) Rewilding in the Western Indian Ocean. Pp. 325-349 in Gerlach, J. (ed.). Western Indian Ocean Tortoises. Manchester: Siri Scientific Press.

Griffiths, O.L. \& Florens, V.F.B. (2006) A field guide to the non-Marine molluscs of the Mascarene Islands (Mauritius, Rodrigues and Réunion) and the Northern Dependencies of Mauritius. Mauritius: Bioculture Press.

Grove, R.H. (1996) Green imperialism: colonial expansion, tropical island Edens and the origins of environmentalism, 1600-1860. Cambridge: Cambridge University Press.

Hansen, D.M. (2010) On the use of taxon substitutes in rewilding projects on islands. Pp. 111-146 in Pérez-Mellado, V. \& Ramon, C. (eds.). Islands and evolution. Institut Menorqi d'Estudis, Recerca 19.

Hansen, D.M. \& Galetti, M. (2009) The forgotten megafauna. Science 324: 42-43.

Hansen, D.M., Donlan, C.J., Griffiths, C.J. \& Campbell, K.J (2010) Ecological history and latent conservation potential: Large and giant tortoises as a model or taxon substitions. Ecography 33: 272-284.

Heaney, L.R. (1991) A synopsis of climatic and vegetational change in Southeast Asia. Climatic Change 19: 53-61.

Hearty, P.J., Olson, S.L., Kaufman, D.S., Edwards, R.L. \& Cheng, H. (2004) Stratigraphy and geochronology of pitfall accumulations in caves and fissures, Bermuda. Quaternary Science Reviews 23: $1151-1171$.

Hume, J.P. (2013) A synopsis of the pre-human avifauna of the Mascarene Islands. Pp. 195-237 in Göhlich, U.B. \& Kroh, A. (eds.). Proceedings of the 8th International Meeting of the Society of Avian Paleontology and Evolution. Wien: Naturhistorisches Museum. 
Hume, J.P. (2014a). Systematics, morphology, and ecological history of the Mascarene starlings (Aves: Sturnidae) with the description of a new genus and species from Mauritius. Zootaxa 3849: 175.

Hume, J.P. (2014b) Fossil discoveries on Mauritius and Rodrigues. Pp. 203-228 in Gerlach, J. (ed.). Western Indian Ocean Tortoises. Manchester: Siri Scientific Press.

Hunt, T.L. (2007) Rethinking Easter Island's ecological catastrophe. Journal of Archaeological Science 34: 485-502.

Hunt, C.O. \& Rabett, R.J. (2014) Holocene landscape intervention and plant food production strategies in island and mainland Southeast Asia. Journal of Archaeological Science 51: 22-33.

Hutton, I., Parkes, J.P. \& Sinclair, A.R.E. (2007) Reassembling island ecosystems: the case of Lord Howe Island. Animal Conservation 10: 22-29.

Johnson, C.N. (2009) Ecological consequences of late Quaternary extinctions of megafauna. Proceedings of the Royal Society of London B 276: 2509-2519

Johnson, T.H. \& Stattersfield, A.J. (1990) A global review of island endemic birds. Ibis 132: 167180.

Keitt, B., Campbell, K., Saunders, A., Clout, M., Wang, Y., Heinz, R. et al. (2011) The Global Islands Invasive Vertebrate Eradication Database: A tool to improve and facilitate restoration of island ecosystems. Pp. 74-77 in: Veitch, C.R., Clout, M.N. \& Towns, D.R. (eds) Island invasives: eradication and management. Switzerland: IUCN.

Lee, W.G., Wood, J.R. \& Rogers, G.M. (2010) The legacy of avian dominated plant-herbivore systems in New Zealand. New Zealand Journal of Ecology 34: 28-47.

Liebherr, J.K. \& Porch, N. (2015) Reassembling a lost lowland carabid beetle assemblage (Coleoptera) from Kauai, Hawaiian Islands. Invertebrate Systematics 29: 191-213.

Loope, L.L., Hughes, R.F. \& Meyer, J-Y. (2013) Plant invasions in protected areas of tropical Pacific Islands, with special reference to Hawaii. Pp. 313-348 in: Foxcroft, L.C. et al. (eds) Plant invasions in protected areas: patterns, problems and challenges. Germany: Springer.

Louys, J. (2008) Quaternary extinctions in Southeast Asia. In: Elewa, A.M.T. (ed) Mass Extinction. Heidelberg: Springer-Verlag.

Louys, J. (2014) The large terrestrial carnivore guild in Quaternary Southeast Asia. Quaternary Science Reviews 96: 86-97.

Louys, J. \& Meijaard, E. (2010) Palaeoecology of Southeast Asian megafauna-bearing sites from the Pleistocene and a review of environmental changes in the region. Journal of Biogeography 37: 1432-1449. 
Louys, J., Curnoe, D. \& Tong, H.W. (2007) Characteristics of Pleistocene megafauna extinctions in Southeast Asia. Palaeogeography, Palaeoclimatology, Palaeoecology 243: 152-173.

Louys, J., Corlett, R.T., Price, G.J., Hawkins, S., Piper, P.J. (2014) Rewilding the tropics, and other conservation translocations strategies in the tropical Asia-Pacific region. Ecology and Evolution 4: 4380-4398.

Louys, J., Price, G.J. \& O’Connor, S. (2016) Direct dating of Pleistocene stegodon from Timor Island, East Nusa Tenggara. PeerJ 4: e1788.

Lyver, P.O'B., Wilmshurst, J.M., Wood, J.R., Jones, C.J., Fromont, M., Bellingham, P.J., et al. (2015) Looking back for the future: local knowledge and palaeoecology inform biocultural restoration of coastal ecosystems in New Zealand. Human Ecology 43: 681-695.

Karels, T.J., Dobson, F.S., Trevino, H.S., Skibiel, A.L. (2008) The biogeography of avian extinctions on oceanic islands. Journal of Biogeography 35: 1106-1111.

King, C.M. (1990) The handbook of New Zealand mammals. Oxford: Oxford University Press.

McGlone, M.S., Wilmshurst, J.M., Leach, H.M. (2005) An ecological and historical review of bracken (Pteridium esculentum) in New Zealand, and its cultural significance. New Zealand Journal of Ecology 29: 165-184.

McWethy, D.B., Wilmshurst, J.M., Whitlock, C., Wood, J.R., McGlone, M.S. (2014) A highresolution chronology of rapid forest transitions following Polynesian arrival in New Zealand. PLoS ONE 9: e111328.

Maloney, B.K. (1980) Pollen analytical evidence for early forest clearance in North Sumatra. Nature 287: 324-326.

Maloney, B.K. (1985) Man's impact on the rainforests of West Malesia: the palynological record. Journal of Biogeography 12: 537-558.

Manne, L.L., Brooks, T.M. \& Pimm, S.L. (1999) Relative risk of extinction of passerine birds on continents and islands. Nature 399: 258-261.

Margano, B.A., Potapov, P.V., Turubanova, S., Stolle, F. \& Hansen, M.C. (2014) Primary forest cover loss in Indonesia over 2000-2012. Nature Climate Change 4: 730-735.

Meehan, H.J., McConkey, K.R. \& Drake, D.R. (2002) Potential disruptions to seed dispersal mutualisms in Tonga, Western Polynesia. Journal of Biogeography 29: 695-712.

Mey, E. (1990) Eine neue ausgestorbene Vogel-Ischnozere von Neuseeland, Huiacola extinctus (Insecta, Phthiraptera). Zoologischer Anzeiger 224: 49-73.

Meyer, J-Y. \& Florence, J. (1996) Tahiti's native flora endangered by the invasion of Miconia calvescens DC. (Melastomataceae). Journal of Biogeography 23: 775-781. 
Minteer, B.A., Collins, J.P., Love, K.E. \&, Puschendorf, R. (2014) Avoiding (re)extinction. Science 344: 260-261.

Miskelly, C.M. \& Powlesland, R.G. (2013) Conservation translocations of New Zealand birds, 18632012. Notornis 60: 3-28.

Miskelly, C.M., Taylor, G.A., Gummer, H. \& Williams, R. (2009) Translocations of eight species of burrow-nesting seabirds (genera Pterodroma, Pelecanoides, Pachyptila and Puffinus: Family Procellariidae). Biological Conservation 142: 1965-1980.

Moree, P.J. (1998) A concise history of Dutch Mauritius, 1598-1710. London: Kegan Paul International, \& Leiden.

Morwood, M.J., Sutikna, T., Saptomo, E.W., Westaway, K.E., Due, R.A., Moore, M.W., et al. (2008) Climate, people and faunal succession on Java, Indonesia: evidence from Song Gupuh. Journal of Archaeological Science 35: 1776-1789.

Nogués-Bravo, D., Simberloff, D., Rahbek, C. \& Sanders, N.J. (2016) Rewilding is the new Pandora's box in conservation. Current Biology 26: R87-R91.

Olson, S.L. \& Wingate, D.B. (2000) Two new species of flightless rails (Aves: Rallidae) from the middle Pleistocene "crane fauna" of Bermuda. Proceedings of the Biological Society of Washington 113: $356-368$.

Page, W.S. \& D’Argent, G. (1997) A vegetation survey of Mauritius. Port Louis: Mauritian Wildlife Foundation.

Pedrono, M., Griffiths, O.L., Clausen, A., Smith, L.L., Griffiths, C.J., Wilme', L. \& Burney, D.A. (2013) Using a surviving lineage of Madagascar's vanished megafauna for ecological restoration. Biological Conservation 159: 501-506.

Perry, G.L.W., Wilmshurst, J.M., McGlone, M.S., McWethy, D.B., Whitlock, C. (2012) Explaining fire-driven landscape transformation during the Initial Burning Period of New Zealand's prehistory. Global Change Biology 18: 1609-1621.

Perry, G.L., Wheeler, A., Wood, J.R. \& Wilmshurst, J.M. (2014) A high-precision chronology for the rapid extinction of New Zealand moa (Aves, Dinornithiformes). Quaternary Science Reviews 105: $126-135$.

Piper, P.J., Rabett, R.J. \& Kurui, E.B. (2008) Using community, composition and structural variation in terminal Pleistocene vertebrate assemblages to identify human hunting behaviour at the Niah Caves, Borneo. Bulletin of the Indo-Pacific Prehistory Association 28: 88-98.

Prebble, M. (2008) No fruit on that beautiful shore: what plants were introduced to the subtropical Polynesian islands prior to European contact. Terra Australis 29: 227-251.

Prebble, M. \& Dowe, J.L. (2008) The late Quaternary decline and extinction of palms on oceanic Pacific islands. Quaternary Science Reviews 27: 2546-2567. 
Prebble, M. \& Wilmshurst, J.M. (2009) Detecting the initial impact of humans and introduced species on island environments in Remote Oceania using palaeoecology. Biological Invasions 11: $1529-1556$.

Rabett, R.J. \& Piper, P.J. (2012) The emergence of bone technologies at the end of the Pleistocene in Southeast Asia: regional and evolutionary implications. Cambridge Archaeological Journal 22: 37 56.

Rando, J.C. \& Alcover, J.A. (2007) Evidence for a second western Palaearctic seabird extinction during the last Millennium: the Lava Shearwater Puffinus olsoni. IBIS 150: 188-192.

Rando J.C., Pieper H. \& Alcover, J.A. (2014). Radiocarbon evidence for house mouse presence on Madeira Island (North Atlantic) one millennium ago. Proceedings of the Royal Society B 281: 20133126.

Rawlence, N.J., Metcalf, J., Wood, J.R., Worthy, T.H., Austin, J.J., Cooper, A. (2012) The effect of climate and environmental change on the megafaunal moa of New Zealand in the absence of humans. Quaternary Science Reviews 50: 141-153.

Rocha, L.A., Aleixo, A., Allen, G., Almeda, F., Baldwin, C.C., Barclay M.V.L., et al. (2014) Specimen collection: an essential tool. Science 344: 814-815.

Roff, D.A. \& Roff, R.J. (2003) Of rats and Maoris: a novel method for the analysis of patterns of extinction in the New Zealand avifauna before European contact. Evolutionary Ecology Research 5: 759-779.

Russell, J.C., Innes, J.G., Brown, P.H. \& Byrom, A.E. (2015) Predator-Free New Zealand: Conservation Country. BioScience 65: 520-525.

Russell, J.C., Meyer, J-Y., Holmes

Sax, D.F. \& Gaines, S.D. (2008) Species invasions and extinction: The future of native biodiversity on islands. Proceedings of the National Academy of Sciences USA 105 (supplement 1): 1149011497.

Schule, W. (1993) Mammals, vegetation and the initial human settlement of the Mediterranean islands: a palaeoecological approach. Journal of Biogeography 20: 399-412.

Seddon, P.J., Strauss, W.M. \& Innes, J. (2012) Animal translocations: what are they and why do we do them? Pp. 1-32 in: Ewen, J.G., Armstrong, D.P., Parker, K.A. \& Seddon, P.J. (eds) Reintroduction Biology: Integrating Science and Management. New Jersey: Wiley-Blackwell.

Seddon, P.J., Griffiths, C.J., Soorae, P.S. \& Armstrong, D.P. (2014) Reversing defaunation: Restoring species in a changing world. Science 345: 406-412.

Shapiro, B. (2015) How to clone a mammoth. USA: Princeton University Press. 
Smith, J.L., Mulder, C.P.H. \& Ellis, J.C. (2011) Seabirds as ecosystem engineers: nutrient inputs and physical disturbance. Pp. 27-55 in: Mulder, C.P.H., Anderson, W.B., Towns, D.R. \& Bellingham, P. J. (eds) Seabird Islands: Ecology, invasion and restoration. New York: Oxford University Press.

Sobral, F.L., Lees, A.C. \& Cianciaruso, M.V. (2016) Introductions do not compensate for functional and phylogenetic losses following extinctions in insular bird assemblages. Ecology Letters 19: 10911100 .

Sodhi, N.S., Koh, L.P., Brook, B.W. \& Ng, P.K.L. (2004) Southeast Asian biodiversity: an impending disaster. Trends in Ecology and Evolution 19: 654-660.

Steadman, D.W. (1995) Prehistoric extinctions of Pacific Island birds: Biodiversity meets zooarchaeology. Science 267: 1123-1131.

Steadman, D.W. (1996) Human-caused extinction of birds. Pp. 139-161 in: Reaka-Kudla, M.L., Wilson, D.E. \& Wilson, E.O. (eds.) Biodiversity II: Understanding and Protecting Our Biological Resources. Washington, D.C.: Joseph Henry Press.

Steadman, D.W. (2006) Extinction \& Biogeography of Tropical Pacific Birds. Chicago: Chicago University Press.

Steadman, D.W., Pregill, G.K. \& Burley, D.V. (2002) Rapid prehistoric extinction of iguanas and birds in Polynesia. Proceedings of the National Academy of Sciences USA 99: 3673-3677.

Swisher, C.C., Curtis, G.H., van den Bergh, G.D., Suprijo, A. \& Widiasmoro. (1994) Age of the earliest known hominids in Java, Indonesia. Science 263: 1118-1121.

Taylor, R. (1979) How the Macquarie Island parakeet became extinct. New Zealand Journal of Ecology 2: 42-45.

Terzopoulou, S., Rigal, F., Whittaker, R.J., Borges, P.A.V. \& Triantis, K.A. (2015) Drivers of extinction: the case of Azorean beetles. Biology Letters 11: 20150273.

Thaman, R. (2002) Threats to Pacific Island biodiversity and biodiversity conservation in the Pacific Islands. Development Bulletin 58: 23-27.

Triantis, K.A., Borges, P.A.V., Ladle, R.J., Hortal, J., Cardoso, P., Gaspar, C. et al. (2010) Extinction debt on oceanic islands. Ecography 33: 285-294.

Turvey, S.T., Oliver, J.R., Narganes, Y.M. \& Rye, P. (2007) Late Holocene extinction of Puerto Rican native land mammals. Biology Letters 3: 193-196.

Valenzuela, A., \& Alcover, J.A. (2013) Radiocarbon evidence for a prehistoric deliberate translocation: the weasel (Mustela nivalis) of Mallorca. Biological Invasions 15: 717-722.

Van Den Bergh, G.D., Li, B., Brumm, A., Grün, R., Yurnaldi, D., Moore, M.W., Kurniawan, I., Setiawan, R., Aziz, F., Roberts, R.G. \& Storey, M. (2016) Earliest hominin occupation of Sulawesi, Indonesia. Nature 529: 208-211. 
Vigne, J.D., Zazzo, A., Saliège, J.F., Poplin, F., Guilaine, J. \& Simmons, A. (2009) Pre-Neolithic wild boar management and introduction to Cyprus more than 11,400 years ago. Proceedings of the National Academy of Sciences USA 106: 16135-16138.

Warner, R.E. (1968) The role of introduced diseases in the extinction of the endemic Hawaiian avifauna. The Condor 70: 101-120.

Watts, C., Stringer, I., Sherley, G., Gibbs, G. \& Green, C. (2008) History of weta (Orthoptera: Anostostomatidae) translocation in New Zealand: lessons learned, islands as sanctuaries and the future. Journal of Insect Conservation 12: 359-370.

Weisler, M.I. (1995) Henderson Island prehistory: colonization and extinction on a remote Polynesian island. Biological Journal of the Linnean Society 56: 377-404.

Wikelski, M., Foufopoulos, J., Vargas, H. \& Snell, H. (2004) Galápagos birds and diseases: invasive pathogens as threats for island species. Ecology and Society 9: 5.

Wilmshurst, J.M., Anderson, A.J., Higham, T.F.G. \& Worthy, T.H. (2008) Dating the late prehistoric dispersal of Polynesians to New Zealand using the commensal Pacific rat. Proceedings of the National Academy of Sciences USA 105: 7676-7680.

Wilmshurst, J.M., Hunt, T.L., Lipo, C.P., Anderson, A.J. (2011) High-precision radiocarbon dating shows recent and rapid initial human colonization of East Polynesia. Proceedings of the National Academy of Sciences USA 108: 1815-1820.

Wilmshurst, J.M., Moar, N.T., Wood, J.R., Bellingham, P., Findlater, A., Robinson, J. \& Stone, C. (2014) Pollen and ancient DNA provide conservation baselines for offshore islands in New Zealand. Conservation Biology 28: 202-212.

Wood, J.R. (2013) New Zealand, 500 years ago. Pp. 595-604 in MacLeod, N. (ed) Grzimek's Animal Life Encyclopedia: Extinction. Farmington Hills, USA: Gale.

Wood, J.R. \& Wilmshurst, J.M. (2017) Changes in New Zealand forest plant communities following the prehistoric extinction of avian megaherbivores. Journal of Vegetation Science 28: 160-171.

Wood, J.R., Wilmshurst, J.M., Holzapfel, A.S., Worthy, T.H. \& Cooper, A. (2012) A lost link between a flightless parrot and a parasitic plant and the potential role of coprolites in conservation paleobiology. Conservation Biology 26: 1091-1099.

Wood, J.R., Wilmshurst, J.M., Rawlence, N.J., Bonner, K.I., Worthy, T.H., Kinsella, J.M. \& Cooper, A. (2013) A megafauna's microfauna: gastrointestinal parasites of New Zealand's extinct moa (Aves: Dinornithiformes). PLoS ONE 8: e57315.

Worthy, T.H. \& Holdaway, R.N. (2002) The lost world of the moa. Christchurch: Canterbury University Press. 
Wyatt, K.B., Campos, P.F., Gilbert, M.T.P., Kolokotronis, S., Hynes, W.H., DeSalle, R. et al. (2008) Historical mammal extinction on Christmas Island (Indian Ocean) correlates with introduced infectious disease. PLOS ONE 3: e3602.

Zazzo, A., Lebon, M., Quiles, A., Reiche, I. \& Vigne, J.D. (2015) Direct dating and physicochemical analyses cast doubts on the coexistence of humans and dwarf hippos in Cyprus. PLoS ONE 10: e0134429.

\section{FIGURE CAPTIONS}

Figure 1. Hypothetical curves describing general patterns in the number of predator introductions and faunal extinctions (cumulative), and the rate of forest loss, associated with human visitation and Holocene settlement of islands.

Figure 2. Holocene extinction phases, timing of introduction of predatory mammal species, and cumulative bird extinction curves (red solid line) for the Mascarenes and New Zealand. For New Zealand, cumulative extinction curves for reptiles/amphibians (green short-dash), mammals (blue long-dash) and plants (yellow dot-dash) are also shown. Data for Mascarenes are from Cheke (2013), and New Zealand from Wood (2013) and King (1990). For interpretation of the references to colour in this figure legend, the reader is referred to the web version of this article

Figure 3. A comparison of broad avifaunal dietary guild changes on Mascarenes and New Zealand. 